\title{
Kepemimpinan Krisis dalam Pengelolaan Sekolah
}

\author{
Sastramayani $^{1} \&$ Badarwan $^{2}$ \\ ${ }^{1}$ Fakultas Keguruan dan Ilmu Pendidikan Universitas Lakidende \\ email: sastramayani.unilaki@gmail.com \\ ${ }^{2}$ Fakultas Tarbiyah dan Ilmu Keguruan IAIN Kendari \\ email: badarwan.kdi@gmail.com
}

\begin{abstract}
Abstrak
Dinamika kepemimpinan pada lembaga pendidikan sejatinya berjalan beriringan dengan perkembangan-perkembangan eksternal. Respons yang tinggi terhadap perubahan-perubahan lingkungan menyebabkan organisasi melakukan adaptasi dan melakukan percepatan-percepatan. Sebaliknya, respon yang rendah terhadap fenomena luar lembaga pendidikan menyebabkan perlambatan. Pemimpin selalu memegang peran kunci dalam setiap peristiwa keorganisasian. Pemimpin dituntut untuk memiliki kepekaan yang tinggi terhadap masalah-masalah yang dihadapi lembaganya. Tulisan ini bertujuan memberi gambaran konseptual tentang kepemimpinan yang dibutuhkan lembaga pendidikan dalam menghadapi perubahan yang sangat cepat. Melalui telaah pustaka ditemukan bahwa kepemimpinan krisis merupakan kompetensi yang mesti dimiliki oleh lembaga pendidikan. Kemampuan organisasi dalam melalui transisi maupun transformasi sangat ditentukan oleh kompetensi ini. Pemimpin yang peka terhadap krisis telah menyadari lebih awal tentang berbagai potensi yang dapat mengganggu aktifitas organisasi. Karenanya mereka memiliki perkiraan-perkiraan sebelum krisis tiba, menyiapkan diri untuk melakukan pengelolaan lembaga pada masa krisis, dan melakukan perbaikan-perbaikan, serta pengembanganpengembangan setelah krisis berlalu. Siklus ini akan terus berjalan di tangan seorang pemimpin krisis, sehingga lembaga pendidikan dapat terus menyesuaikan diri di tengah gerak perubahan yang sangat cepat.
\end{abstract}

Kata Kunci: Kepemimpinan Krisis, Sekolah, Pengelolaan 


\title{
Crisis Leadership in School Management
}

\author{
Sastramayani $^{1}$ \& Badarwan $^{2}$ \\ ${ }^{1}$ Fakultas Keguruan dan Ilmu Pendidikan Universitas Lakidende \\ email: sastramayani.unilaki@gmail.com \\ ${ }^{2}$ Fakultas Tarbiyah dan Ilmu Keguruan IAIN Kendari \\ email: badarwan.kdi@gmail.com
}

\begin{abstract}
The dynamics of leadership in educational institutions actually go hand in hand with external developments. The high response to environmental changes causes the organization to adapt and accelerate. Conversely, low responses to phenomena outside educational institutions cause a slowdown. The leader always holds a key role in every organizational event. Leaders are required to have a high sensitivity to the problems facing their institution. This paper aims to provide a conceptual overview of the leadership needed by educational institutions in dealing with rapid changes. Through literature review, it is found that crisis leadership is a competency that must be possessed by educational institutions. Organizational ability through transition and transformation is largely determined by this competency. Crisis-sensitive leaders have realized earlier about various potentials that can interfere with organizational activities. Therefore they have estimates before the crisis arrives, prepare themselves to carry out the management of institutions during the crisis, and make improvements, and developments after the crisis has passed. This cycle will continue in the hands of a crisis leader, so that educational institutions can continue to adjust in the midst of rapid change.
\end{abstract}

Keywords: Crisis Leadership, Schools, Management 


\section{Pendahuluan}

Lembaga pendidikan sejatinya berurusan dengan persoalanpersoalan publik. Posisi ini mengharuskan respon yang tinggi terhadap persoalan-persoalan sosial. Hal ini terkait dengan persoalan etika dan tanggung jawab sosial, dan juga mutu lembaga pendidikan ${ }^{1}$. Ikhtiar memberi respon atas persoalan-persoalan diwujudkan dengan memberikan layanan yang relevan dengan kebutuhan masyarakat, maupun melakukan transformasi kelembagaan.

Keinginan untuk memberikan layanan terbaik maupun transformasi kelembagaan, tidak selalu berbanding lurus dengan kenyataan. Karenanya dibutuhkan kesiapan-kesiapan pada berbagai aspek, agar lembaga tidak gugup dalam menghadapi perubahan ${ }^{2}$. Kesiapan-kesiapan tersebut dapat mencakup persoalan struktur kelembagaan, sumber daya manusia, penggunaan kekuasaan, budaya organisasi, dan terutama kepemimpinan ${ }^{3}$.

Tanggung jawab pemimpin strategi adalah menghadapi krisis. Krisis dapat menyerang sebuah organisasi tanpa peringatan. Krisis berdasarkan sifatnya adalah peristiwa yang dapat diprediksi atau diantisipasi sebelum kejadian tersebut. Oleh karena itu, sulit untuk menghindarinya. Krisis memang merusak organisasi jika tidak dikelola dengan benar. Dalam sebuah krisis, harga saham anjlok dan meningkatkan biaya-biaya operasi, menyebabkan menurunnya keuangan jangka pendek maupun jangka panjang. Krisis yang tidak terkelola dapat juga merusak reputasi organisasi dan mengurangi kepercayaan konsumen pada misi organisasi, atau dalam beberapa kasus menyebabkan kehancurannya sama sekali. Organisasi dalam krisis juga cenderung bertahan dan rentan terhadap serangan para pesaing. Ahli Strategi yang efektif harus mempunyai keahlian yang diperlukan untuk mengelola krisis dengan sukses ${ }^{4}$.

${ }^{1}$ Syahrul, S. (2017). Tanggung Jawab Sosial Pesantren: Studi pada Pondok Pesantren Al Munawwarah Pondidaha, Konawe. Shautut Tarbiyah, 23(2), 120-134.

${ }^{2}$ Syahrul, S. (2016). Readines Frame: Analisis Kerangka Kesiapan dalam Transformasi Pendidikan Tinggi (Pengalaman Iain Kendari). Al-Ta'dib, 9(1), 162181.

3 Bolman, L. G., \& Deal, T. E. (1991). Reframing organizations. San Francisco: Jossey-Bass Publishers.

4 Achua, C. F., \& Lussier, R. N. (2013). Effective leadership. SouthWestern Cengage Learning. 
Lembaga pendidikan pada semua jalur dan jenjang, sedang menghadapi tantangan pengembangan disebabkan kompetisi antar sekolah yang semakin ketat ${ }^{5}$. Beberapa sekolah berhasil tampil sebagai sekolah unggulan di tengah persaingan tersebut, tetapi lebih banyak lagi yang mengalami stagnasi, bahkan cenderung mengalami kemunduran. Kedua kondisi tersebut adalah gambaran dari persoalan kepemimpinan, bahwa maju mundurnya sebuah sekolah sangat bergantung pada pemimpinnya ${ }^{6}$.

Tulisan ini mencoba memberi lukisan konseptual tentang penting kepemimpinan krisis pada lembaga pendidikan yang kompetitif. Bahwa pemimpin yang dibutuhkan adalah mereka yang memiliki kompetensi yang memadai dalam menghadapi krisis, mengelola krisis, dan melakukan konsolidasi pasca krisis.

\section{Metode}

Artikel ini merupakan kajian literatur tentang salah satu aspek dari kepemimpinan yaitu kepemimpinan krisis. Bahan review berasal dari artikel ilmiah dan buku yang relevan, dibatasi dalam sepuluh tahun terakhir. Hasil kajian dianalisis dengan melakukan pengelompokan, klasifikasi, dan pengkategorian tema. Selanjutnya dilakukan analisis terhadap tema yang memiliki pertentangan maupun persamaan makna. Terakhir adalah memberi makna atas hubungan antar tema dalam konteks kepemimpinan krisis.

\section{Kompetensi Kepemimpinan Krisis Bagi Kepala Sekolah}

Salah satu fungsi dari kepala sekolah adalah fungsi kepemimpinan $^{7}$, dan pembuat inovasi ${ }^{8}$. Pergantian kepemimpinan, persaingan antar sekolah, maupun kekacauan internal aparat sekolah, serta perilaku peserta didik yang tidak terkendali, menjadi pertanda

${ }^{5}$ Hakim, M. N. (2016). Implementasi Manajemen Berbasis Sekolah Dalam Mewujudkan Sekolah Islam Unggulan. Nidhomul Haq: Jurnal Manajemen Pendidikan Islam, 1(2), 104-114.

6 Fitrah, M. (2017). Peran kepala sekolah dalam meningkatkan mutu pendidikan. Jurnal Penjaminan Mutu, 3(1), 31-42.

${ }^{7}$ Warsono, H., \& Dwimawanti, I. H. (2016, July). The Model Organization of Early Childhood Education in Organizational Capacity Development. In 2016 International Conference on Public Management. Atlantis Press.

8 Syahrul, S. (2015). Kepemimpinan dan Inovasi Lembaga Pendidikan (Pengalaman Pondok Gontor VII Putra Sulawesi Tenggara). Al-Ta'dib, 8(1), 82-100. 
bahwa sebuah sekolah sedang mengalami krisis. Karenanya, fungsifungsi kepemimpinan di atas mesti diterapkan, terutama bagi para pemimpin baru. Krisis adalah kejadian berdampak tinggi yang mengancam kelangsungan hidup organisasi dengan ciri ambiguitas penyebab, efek, dan cara penyelesaian, maupun kepercayaan bahwa keputusan harus dibuat secara cepat ${ }^{9}$. Salah mengelola hari ini dan karirmu mungkin berakhir dalam kesedihan ${ }^{10}$. Krisis dapat terjadi dimana saja, kapan saja, dan kepada siapa saja. Krisis tidak memandang bulu, dan yang lebih penting adalah ketika krisis tidak pernah diperhitungkan sehingga menyebabkan kebingungan ketika ia tiba $^{11}$.

Pengelolaan krisis pada setiap rencana strategis organisasi adalah mendesak ${ }^{12}$. Situasi krisis menyebabkan sebuah lembaga pendidikan berada dalam ketidak pastian ${ }^{13}$. Sayangnya, rencanarencana respons krisis tidak tersebar luas sebagaimana diharapkan. Hasil-hasil survey terbaru mengungkapkan bahwa sekitar 53 persen eksekutif marketing mengatakan mereka berpengalaman mengasilkan krisis bisnis dalam liputan berita negatif, penjualan menurun, atau keuntungan berkurang. Secara mengejutkan, jumlah yang sama (57 persen) mengatakan perusahaan mereka tidak melakukan rencana respon krisis di tempat saat ini. Banyak ahli dan ilmuwan setuju bahwa ketika rencana respon pra-krisis tidak mencegah sebuah krisis, hal itu dapat mengurangi kerugian keuangan, dan kerusakan jangka panjang terhadap reputasi perusahaan ${ }^{14}$.

Lembaga pendidikan yang proaktif menggunakan perencanaan strategik dan rencana-rencana kesiapan krisis, mengambil langkahlangkah yang tepat mendesain alat dan system untuk merespon krisis

9 Badarwan, B. (2018). Dinamika Sekolah Pinggiran dalam Perspektif Kepemimpinan Krisis di Kota Kendari. Shautut Tarbiyah, 24(2), 181-203.

${ }^{10}$ Achua, C. F., \& Lussier, R. N. (2013). Effective leadership. SouthWestern Cengage Learning

${ }^{11}$ Purwaningwulan, M. M., Sos, S., \& Si, M. (2013). Public Relations dan Manajemen Krisis. ILMU KOMUNIKASI, 11.

12 Suharyanti, S., \& Sutawidjaya, A. H. (2013). Analisis Krisis Pada Organisasi Berdasarkan Model Anatomi Krisis dan Perspektif Public Relations. Journal Communication Spectrum, 2(2).

${ }^{13}$ Syahrul, S. (2017). Perencanaan Strategis dan Praktiknya di Perguruan Tinggi. Shautut Tarbiyah, 23(1), 142-159.

14 Achua, C. F., \& Lussier, R. N. (2013). Effective leadership. SouthWestern Cengage Learning 
secara efektif sebelum terjadi. Kepemimpinan krisis strategik mensyaratkan tiga hal: 1) Menggunakan teknik-teknik pemantauan lingkungan untuk mengenali peristiwa yang dapat memicu krisis di masa depan; 2) Menyatukan manajemen krisis kedalam proses manajemen strategik sehingga tetap menjadi bagian dari proses strategi evaluasi secara keseluruhan; 3) Membangun budaya yang merangkul kesadaran dan persiapan krisis sebagai sebuah jalan hidup ${ }^{15}$.

Bentuk-bentuk krisis, antara lain: bencana alam seperti badai dan tsunami, serangan teroris, kegagalan produk human error, kematian CEO yang tidak diharapkan dan kegagalan system ${ }^{16}$. Adapula krisis yang tidak selalu di halaman depan koran atau tampil di berita TV, seperti pelecehan seksual, kelakuan buruk eksekutif, penarikan ulang produk, dan peretasan computer. Terlepas dari sifat krisis, mereka semua memiliki kesamaan yakni stress dan tekanan yang menempatkan mereka pada kunci system dan sumber daya organisasi. Suatu kelemahan yang mungkin telah ada dalam system sebelum sebuah krisis terbuka dan berlanjut pada konsekwensi negatif dari krisis. Suatu krisis memiliki potensi untuk merusak reputasi, kredibilitas, integritas, dan posisi keuangan perusahaan ${ }^{17}$.

\section{A. Mengenali Lingkungan}

Peristiwa yang terjadi pada lingkungan organisasi terkini menggarisbawahi pentingnya kepemimpinan krisis. Karena ekonomi dan spekulasi yang menggesernya ke dalam resesi, prospek nyata yang terlihat yang mana banyak organisasi menghadapi krisis kelangsungan hidup. Sehingga orang mencari pemimpin yang dapat memberikan

15 Achua, C. F., \& Lussier, R. N. (2013). Effective leadership. SouthWestern Cengage Learning

16 Adnan, M. A., \& Kumiasih, E. (2000). Analisis tingkat kesehatan perusahaan untuk memprediksi potensi kebangkrutan dengan pendekatan Altman (Kasus pada sepuluh perusahaan di Indonesia). Indonesian Journal of Accounting and Auditing, 4(2), 131-161.

17 Suharyanti, S., \& Sutawidjaya, A. H. (2013). Analisis Krisis Pada Organisasi Berdasarkan Model Anatomi Krisis dan Perspektif Public Relations. Journal Communication Spectrum, 2(2). 
stabilitas, jaminan kembali, kepercayaan, dan rasa control selama dan sesudah krisis $^{18}$.

Mengantisipasi jenis-jenis krisis yang sebuah organisasi temui tidaklah mudah bagi seorang pemimpin. Ribuan insiden dapat memberikan krisis dan rintangan upaya-upaya organisasi untuk meraih kesuksesan dalam tujuan-tujuan strategik. Masalah yang mendeteksi sinyal-sinyal yang memperingatkan tentang sebuah krisis. Banyak organisasi dihadirkan dengan sinyal-sinyal peringatan dini tentang krisis mendatang tetapi gagal mengenali dan mengindahkan mereka. Krisis dapat memberikan peluang bagi organisasi untuk belajar dan beradaptasi ketika terkena krisis berikutnya. Oleh karena itu, tingkat kepedulian yang sama diinvestasikan dalam menempatkan bersama sebuah rencana strategik untuk pertumbuhan, stabilitas, atau pembaharuan yang harus dibaktikan untuk perencanaan krisis ${ }^{19}$.

Sebuah studi merasakan pentingnya perencanaan krisis bagi bisnis kecil menemukan bahwa perhatian dalam perencanaan krisis dimotivasi oleh peristiwa krisis dari pada perilaku proaktif manajemen. Dengan kata lain, komitmen bisnis kecil terhadap perencanaan krisis bukan karena cara pandang proaktif pemimpinnya, tetapi lebih pada sejarah krisis masa lalu organisasi. Pendekatan ini berbahaya karena mungkin saja tidak selalu ada kesempatan kedua untuk belajar dari kesalahan ${ }^{20}$.

\section{B. Rencana Pengelolaan Krisis Sekolah}

Meskipun menderita kerugian, manajemen yang tepat dapat mengurangi lamanya sebuah krisis, meningkatkan atau mempertahankan citra perusahaan yang bertanggung jawab secara sosial dan mengamankan keuntungan di masa depan ${ }^{21}$. Manajemen

18 Achua, C. F., \& Lussier, R. N. (2013). Effective leadership. SouthWestern Cengage Learning

${ }^{19}$ Lestari, D. I. (2013). Penerapan Strategi Komunikasi Krisis Terhadap Krisis Akibat Pemberitaan Media Tentang Kasus Korupsi Pengadaan Pupuk: Studi Kasus Hubungan Media Humas PT Perkebunan Nusantara XII (PERSERO) Surabaya. Jurnal Ilmu Komunikasi.

${ }^{20}$ Achua, C. F., \& Lussier, R. N. (2013). Effective leadership. SouthWestern Cengage Learning

21 Suharyanti, S., \& Sutawidjaya, A. H. (2013). Analisis Krisis Pada Organisasi Berdasarkan Model Anatomi Krisis dan Perspektif Public Relations. Journal Communication Spectrum, 2(2). 
krisis yang efektif tergantung pada perencanaan dan orang. Menurut para ahli di lapangan, rencana manajemen krisis yang efektif adalah : (1) komprehensif, dengan tugas kepemimpinan, team, dan individu yang jelas dalam bentuk peran dan tanggung jawab; (2) menaikan frekuensi dan dukungan melalui latihan dan sesi praktek berkalal dan (3) kordinasi dan control pada semua tingkat dan unit organisasi. Secara kolektif, tiga persayarata tersebut Nampak menunjuk pada pentingnya pengembangan sumber daya manusia dalam manajemen krisis $^{22}$. dari:

Kesiapan merespons sebuah krisis secara tepat adalah fungsi

1. Pengetahuan dan penerimaan peran seseorang yang ditugaskan dalam rencana manajemen krisis;

2. Pelatihan khusus yang memadai terkait peran penugasan yang memungkinkan seseorang menunjukkan tanggung jawabnya secara kompeten.

3. Melengkapi dan menyatukan peran dan tanggung jawab pada semua level organisasi, sehingga respons manajemen krisis terkontrol dan terkoordinasi ${ }^{23}$.

Rencana manajemen krisis harus menuju apa yang terjadi sebelum, selama, dan sesudah krisis. Rencana pra-krisis ada langkah pertama dari suatu program manajemen krisis. Hal ini memungkingkan organisasi untuk menetapkan prosedur dan praktek bagi analisis risiko, deteksi sinyal secara dini, dan tindakan pencegahan. Selama krisis, eksekusi yang berhasil dari perbaikan rencana yang dipersiapkan merusak kendali dan pemulihan; and setelah krisis, pembelajaran dan perubahan organisasi adalah vital bagi keberlanjutan hidup di masa depan ${ }^{24}$.

\section{Perencanaan Sebelum Krisis}

\section{Manfaat Perencanaan Sebelum Krisis}

Meskipun tidak ada orang yang dapat mengembangkan rencana pra-krisis yang akan mengantisipasi dan menunjukkan secara

${ }^{22}$ Suharyanti, S., \& Sutawidjaya, A. H. Ibid

${ }^{23}$ Achua, C. F., \& Lussier, R. N. (2013), op.cit

24 Aditya, V., \& Nasrianti, L. F. (2017). KOMUNIKASI KRISIS DI SOSIAL MEDIA Analisis Manajemen Krisis Iklan\# PilihAman Grab Bike Indonesia. Prosiding Magister Ilmu Komunikasi, 1(2). 
akurat kemungkinan di masa depan, hal itu masih cara terbaik meringankan konsekwensi negative sebuah krisis. Rencana pra-krisis memungkinkan para pemimpin dan pengikut mereka membuat keputusan yang baik di bawah tekanan yang berat, di dalam banyak kesulitan, dan keadaan tidak menyenangkan ${ }^{25}$. Banyak orang jarang merenungkan kemungkinan sebuah kebakaran, kekerasan tema sekerja, perampokan, ataupun bencana alam yang dapat terjadi di mana mereka bekerja. Kecenderungan untuk mengembangkan detasemen mental dari isu -itu terjadi pada orang lain bukan pada saya atau organisasi kami. Beberapa pemimpin merasionalisasikan bahwa system yang ada memadai untuk menyalurkan dengan krisis tersebut seharusnya mereka muncul, ketika yang lain menemukan hiburan dalam pendekatan "berpikir positif" (tidak ada yang buruk akan terjadi). Penolakan terhadap terjadinya peristiwa probabilitas rendah ini menciptakan pemikiran yang tak terpikirkan sebuah tantangan kepemimpinan utama. Pemimpin yang dapat mengatasi hambatan psikologis ini dan merasakan risiko secara realistis can mendekati manajemen pra-krisis dalam logika dan cara sistematik. Sebuah studi menyelidiki hubungan antara kesiapsiagaan krisis dan kinerja perusahaan menemukan bahwa organisasi berkinerja tinggi memiliki tingkat kesiagsiagaan krisis yang tinggi. Studi yang sama juga melaporkan bahwa belajar dari kegagalan adalah fasilitator penting kesiapsiagaan pada krisis di masa depan.

\section{Aspek-Aspek Pase Perencanaan Sebelum Krisis}

Perencanaan pra-krisis mensyaratkan tiga komponen yang mana setiap organisasi (besar, kecil, profit, non-profit) harus menunjukkan ketika menempatkan bersama sebuah rencana respons krisis yang komprehensif: (1) menunjuk seorang pemimpin krisis, (2) menciptakan tim respons krisis, dan (3) menilai risiko. Kami akan gambarkan secara singkat masing-masing secara terpisah ${ }^{26}$.

Pemimpin Krisis, adalah eksekutif senior yang bertugas mengamati dan mengawasi lingkungan internal dan eksternal bagi

\footnotetext{
${ }^{25}$ Purwaningwulan, M. M., Sos, S., \& Si, M. (2013). Public Relations dan Manajemen Krisis. ILMU KOMUNIKASI, 11.

${ }^{26}$ Achua, C. F., \& Lussier, R. N. (2013), op.cit
} 
potensi tantangan ataupun tanda peringatan sebuah krisis ${ }^{27}$. Dalam peristiwa krisis, pemimpin harus dapat melihat, mengontrol, dan mengawasi semua aspek dari rencana eksekusi. Pemimpin krisis mungkin melaporkan secara langsung kepada CEO atau kepada kepala komunikasi ataupun public relation. Pekerjaan utama dari pemimpin krisis dapat mencakup kegiatan sebagai berikut:

a. Mensyaratkan individu atau pun departemen untuk menjaga daftar keluhan ataupun insiden

b. Memantau perilaku dan keluhan pegawai dan pelanggan

c. Mengidenfikasi pola-pola yang muncul atau tren dalam lingkungan peraturan, pemandangan kompetisi, dan lingkungan sosial.

d. Mengkoordinasikan kegiatan tim manajemen krisis untuk menjamin bahwa anggota bekerja bersama dengan baik ${ }^{28}$.

Kemampuan pemimpin krisis memahami dampak peristiwa dalam tahap pengembangan dini telah membantu beberapa organisasi mencegah krisis dan membantu yang lainnya mengubah krisis menjadi peluang. Atribut atau kualitas pemimpin krisis yang efektif mencakup keahlian tambahan dengan memberikan pengalaman nyata melalui krisis, wawasan, pengaruh, tidak mementingkan diri sendiri, dan pragmatism $^{29}$.

Untuk menjadi efektif, pemimpin krisis harus memiliki kekuasaan, sumber daya, posisi, dan stature untuk mempengaruhi peristiwa ketika krisis meletus. Contohnya, sebuah organisasi harus memberdayakan pemimpin krisis untuk membuat keputusan kritis seperti mematikan garis produk jika sebuah cacat ditemukan, atau operasi yang terputus-putus pada perakitan jika banyak cedera dan salah fungsi telah dilakukan.

Tim Respons Krisis berfungsi meningkatkan kemampuan organisasi merespon krisis secara cepat dan efektif. Tim respons krisis seharusnya melibatkan percampuran perwakilan dengan baik dari

${ }^{27}$ Kristiawan, A., \& Yunanto, K. T. (2012). Pemimpin, Budaya Organisasi, dan Perilaku Etis. In Prosiding Seminar Nasional.

${ }^{28}$ Achua, C. F., \& Lussier, R. N. (2013), op.cit

${ }^{29}$ Lestari, D. I. (2013). Penerapan Strategi Komunikasi Krisis Terhadap Krisis Akibat Pemberitaan Media Tentang Kasus Korupsi Pengadaan Pupuk: Studi Kasus Hubungan Media Humas PT Perkebunan Nusantara XII (PERSERO) Surabaya. Jurnal Ilmu Komunikasi. 
semua sektor organisasi ${ }^{30}$. Hal itu seharusnya menarik kritik sumber daya internal dan sumber daya eksternal.

Pendekatan tim ini berhubungan dengan banyak praktek organisasi, yang membagi pekerjaan manajemen krisis melalui di seluruh organisasi tanpa sebuah komando pusat. Pengalaman mengungkapkan bahwa pendekatan pembagian ini sering berhasil dalam konflik -kadang didorong oleh ideology, alokasi sumber daya, ataupun politik kantor- lebih hanya yang bertanggung jawab tunggal bagi pengelolaan krisis. Dalam situasi ini, tidak jarang untuk memiliki direktur berbagai bagian perusahaan yang membantah bahwa mereka dan staff mereka yang terbaik lengkap untuk mengelola krisis, sering tidak disetujui oleh direktur lainnya ${ }^{31}$.

Tim yang efektif berfungsi sebagai satu unit dengan satu suara di bawah komando unit tunggal. Sebagai tim yang terdiri dari anggota yang dapat menantang ide-ide satu sama lain tanpa beralih para serang personal, mengikut sertakan dalam debat tanpa pemaksaan ataupun menyalahkan, dan berasatu di belakang keputusan yang sekali mereka buat. Anggota tidak mengelakkan ataupun merusak satu sama lain; malah mereka bekerja secara kooperatif, berbagi informasi dan meningkatkan kerja tim. Kesatuan dan semangat ini mencegah tim dari penyelewengan fungsi. Dalam kata seorang ahli, "jika tim adalah disfungsional sebelum krisis, maka tiim akan memiliki respons disfungsional selama insiden" ${ }^{32}$.

Penilaian Risiko Krisis. Penilaian krisis adalah alat umum yang digunakan dalam perencanaan krisis. Meminjam dari lapangan manajemen risiko, tim krisis yang ditetapkan untuk mengidentifikasi potensi insiden yang dapat mengenai organisasi dan kemudian menentukan peringkat kesiapsiagaan yang perlu ${ }^{33}$. Sebuah krisis akan berdampak negative pada organisasi, orang, kondisi keuangan, ataupun citra. Pemimpin krisis dan anggota tim krisis memulai proses penilaian risiko dengan melibatkan dalam analisis skenario "ApakahJika" yang fokus pada penciptaan insiden yang realistis di bawah setiap kategori krisis. Perencanaan dan analisis skenario adalah alat

${ }^{30}$ Sa'diyah, H. (2018). Manajemen Krisis Universitas Islam Indonesia (UII) Yogyakarta dalam Mengatasi Kasus Mapala Unisi. Jurnal Ilmu Komunikasi AKRAB, 2(1).

${ }^{31}$ Achua, C. F., \& Lussier, R. N. (2013), Ibid

${ }^{32}$ Achua, C. F., \& Lussier, R. N. (2013), Ibid

${ }^{33}$ Hanafi, M. (2014). Manajemen risiko. 
yang membantu pemimpin mencegah ataupun merespon krisis melalui keahlian mengambil keputusan berdasarkan pada hasil krisi yang mungkin. Anggota mungkin menjawab pertanyaan seperti, "Apakah yang dapat terjadi? Dimana kita rentan? Apakah skenario terburuk? Apakah pandangan jangka pendek dan jangka panjang nya?". Ini adalah seri perangkat scenario "What-If" tahap lima langkah rencana penilaian risiko ${ }^{34}$.

Lima langkah proses penilaian risiko terdiri dari (1) identifikasi risiko, (2) peringkat dan penilaian risiko, (3) pengurangan risiko, (4) pencegahan krisis, dan (5) manajemen krisis. Kelima langkah proses penilaian risiko di atas dijelaskan sebagai berikut:

Pertama, Kegiatan dalam identifikasi risiko anggota tim krisis akan memulai dengan mengidentifikasi insiden terburuk yang dapat memiliki akibat yang parah pada orang, posisi keuangan organisasi, ataupun citra. Proses ini digambarkan sebagai hasil dan identifikasi risiko dalam pembuatan sebuah bagan risiko.

Kedua, Peringkat dan penilaian risiko, dimana insiden-insiden dianalisis dan diranking dengan menggunakan criteria tertentu. Pengurangan risiko menugaskan pemimpin krisis membagikan bagan risiko yang telah dibuat selama penilaian dan pemeringkatan risiko bersama anggota tim ataupun audiens besar, dan mereka memulai perdebatan dan perumusan strategi-strategi untuk menghadapi setiap krisis maupun tantangan. Analisis SWOT masuk dalam permainan sebagai alat dalam menentukan "Apakah sumber daya dan kemampuan yang disediakan atau dibutuhkan untuk mengelola setiap krisis dengan lebih baik".

Ketiga, Tahap berikutnya adalah pencegahan risiko. Selama pencegahan krisis, pengujian dan simulasi dilakukan untuk menguji pegawai di bawah tekanan. Informasi analisis SWOT digunakan untuk menyempurnakan langkah ini. Langkah ini membantu membuat peka organisasi terhadap kebutuhan akan perencanaan krisis. Setelah pengujian, simulasi, diskusi hasil, evaluasi, dan umpan balik dari manajer pada semua level organisasi, tim krisis kemudian dapat tenang dengan jaminan bahwa organisasi telah dipersiapkan sangat baik untuk menghadapi krisis.

\footnotetext{
${ }^{34}$ Achua, C. F., \& Lussier, R. N. (2013), op.cit
} 
Keempat, Sebuah tim dirakit dan disiapkan untuk merespon peristiwa krisis yang nyata ${ }^{35}$.

Akhirnya, ukuran terbaik untuk menentukan kesiapan organisasi untuk merespon sebuah krisis adalah bagaimana kecepatannya menurut 5 (lima) faktor berikut :

1. Kualitas rencana krisis strategis

2. Kesadaran dan akses terhadap informasi manajemen krisis

3. Kesiapan untuk tanggap cepat.

4. Rencana komunikasi yang efektif di tempat

5. Kepemimpinan krisis yang efektif ${ }^{36}$

Rencana krisis yang komprehensif berdasarkan pada analisis risiko yang menunjukkan siapa yang berkuasa membuat keputusan kunci, siapa di dalam tim dan apa peran dan tanggung jawab mereka, dan apakah karyawan disyaratkan atau tidak untuk melakukan ataupun mengatakan. Rencana ini dapat berarti membedakan antara keberlangsungan hidup dengan kematian total organisasi. Manfaat dari rencana pra krisis adalah jelas -waktu respon cepat, pertimbangan yang lebih baik, siap dan tersedia sumber daya, tingkat kesalahan rendah, kurang kepanikan, dan alat resolusi krisis terbaik ${ }^{37}$.

\section{Mengelola Selama Krisis}

Respons yang efektif dalam peristiwa krisis adalah syarat bagi keberlangsungan hidup organisasi. Organisasi seharusnya membuat dirinya sendiri diakses secara cepat dan terbuka. Umumnya dipercaya bahwa dalam satu jam menjadi sadar bahwa bahwa situasi krisis mungkin ada, sehingga pejabat perusahaan harus dipersiapkan untuk mengeluarkan pernyataan awal kepada media dan kelompok stakeholder kunci lainnya -menyediakan fakta-fakta sebagaimana yang mereka ketahui dan indikasi ketika rincian tambahan akan disediakan. Tujuan dari respons cepat pada bagian yang mempengaruhi organisasi adalah untuk mengisi kekosongan informasi dengan perspektif dan fakta-fakta. Tindakan cepat dapat membantu mempertahankan kredibilitas dan reputasi organisasi dan

35 Istiningrum, A. A. (2011). Implementasi penilaian risiko dalam menunjang pencapaian tujuan instansi pendidikan. Jurnal Pendidikan Akuntansi Indonesia, 9(2).

${ }^{36}$ Achua, C. F., \& Lussier, R. N. (2013), op.cit

37 Badarwan, B. (2018). Dinamika Sekolah Pinggiran dalam Perspektif Kepemimpinan Krisis di Kota Kendari. Shautut Tarbiyah, 24(2), 181-203. 
pemimpinnya selama krisis. Pengalaman menunjukkan bahwa lamanya perusahaan menunggu, lebih memungkinkan kekosongan diisi dengan pernyataan yang tidak akurat dan sekaligus kesalahan informasi yang diterima sebagai kebenaran ${ }^{38}$.

Peran Pemimpin Senior ${ }^{39}$. Derajat kesiapsiagaan organisasi pada potensi krisis tergantung pada pemimpin senior dan personil bertanggung jawab lainnya. Ketika ada krisis, karyawan akan mencari bimbingan dari pemimpin senior perusahaan tentang bagaimana operasi bisnis dilanjutkan dan cara-cara mengatasi situasi tersebut. Sayangnya, beberapa pemimpin senior telah mengetahui untuk mundur di belakang pintu-pintu tertutup ketika krisis terjadi. Mereka mendelegasikan kepada manajer bawah tugas menghadapi media dan kelompok stakeholder lainnya. Tiga prinsip kunci kepemimpinan krisis menurut beberapa ahli, yakni: (1) tetap bertahan dan memimpin dari depan, (2) fokus pada gambar besar dan mengkomunikasikan visi, dan (3) bekerja dengan tim manajemen krisis. Organisasi dengan tim manajemen yang mapan dapat berkomunikasi dan merespons selama krisis ${ }^{40}$.

Pada saat krisis, pemimpin yang efektif mencoba tidak untuk kalah melihat gambar besar. Mereka tinggal fokus pada visi dan misi organisasi meskipun berurusan dengan realitas yang ada. Pemimpin efektif mengandalkan nilai dan prinsip yang ditemukan dalam pernyataan misi mereka untuk memandu pengambilan keputusan perusahaan selama krisis. Ada kepercayaan yang kuat bahwa mereka dan pengikut mereka akan menang.

Pemimpin efektif memandang manajemen krisis sebagai sebuah upaya tim. Mereka mengerti secara jelas bahwa itu tepat pada saat ini bahwa pemimpin yang baik membutuhkan tim yang dapat menawarkan nasihat yang bijaksana, dan menantang debat inti pandangan tanpa paksaan, dan menantang satu sama lain tanpa menyalahkan, sehingga tiba pada sebuah consensus di waktu yang tepat. Pada waktu krisis, sebuah tim dengan keseimbangan lengkap

${ }^{38}$ Nova, F. (2009). Crisis public relations: bagaimana PR menangani krisis perusahaan. Grasindo.

39 MAULANA, H., \& VERAWATI, V. (2014). PENGARUH GAYA KEPEMIMPINAN TRANSFORMASIONAL TERHADAP KETERIKATAN KARYAWAN: STUDI PADA PT. PERTAMINA (PERSERO). JPPP-Jurnal Penelitian dan Pengukuran Psikologi, 3(2), 47-51.

${ }^{40}$ Achua, C. F., \& Lussier, R. N. (2013), op.cit 
keahlian dan bakat dapat bergerak secara cepat dan efektif. Ini adalah memiliki perencanaan pra-krisis dan penilaian risiko membayar dividen besar dan sering diartikan perbedaan antara keberlangsungan hidup dengan kepunahan. Pemimpin tidak hanya harus mencari nasihat yang bijaksana dari timnya, ia seharusnya juga menanamkan rasa persahabatan yang kuat di antara semua karyawan dengan membolehkan mereka berbagi emosi dan perasaan mereka satu sama lain di dalam kelompok.

\section{E. Komunikasi Krisis yang Efektif}

Komunikasi krisis yang efektif penting karena ia dapat membuat ataupun merusak reputasi lembaga pendidikan ${ }^{41}$. Dari beberapa tahun lalu, telah menjadi makin jelas bahwa pemeliharaan sebuah system komunikasi krisis yang efektif dengan stakeholder utama -karyawan, pelanggan, anggota dewan, media berita, badan pengawas- adalah kritis bagi keberlangsungan hidup ketika krisis terjadi. Perencanaan pra-krisis yang efektif seharusnya menunjuk siapa yang akan berbicara untuk organisasi dalam peristiwa krisis. Staf Public Relation dapat menjawab pertanyaan dari media ketika staf legal mungkin merespon pertanyaan-pertanyaan legal. Umumnya dipercaya bahwa hal itu akan membuat perbedaan Apakah itu perwakilan perusahaan, atau juru bicara manajer level senior, ataupun seseorang pada level tanggung jawab paling bawah. Tingkat senioritas menunjukkan kepada publik keseriusan dengan mana insiden dilihat ${ }^{42}$.

System komunikasi yang dirancang dengan baik seharusnya memberitahu karyawan pada semua level siapa yang harus dihubungi, prosedur apa yang harus diikuti, dan apa yang mereka seharusnya dan tidak seharusnya kepada bermacam individu dan lembaga ${ }^{43}$. Demikian juga prosedur seharusnya memberitahu manajer dengan tepat apakah peran mereka akan dimainkan dalam peristiwa krisis, dan bagaiman

41 Suharyanti, S., \& Sutawidjaya, A. H. (2013). Analisis Krisis Pada Organisasi Berdasarkan Model Anatomi Krisis dan Perspektif Public Relations. Journal Communication Spectrum, 2(2).

${ }^{42}$ Lestari, D. I. (2013). Penerapan Strategi Komunikasi Krisis Terhadap Krisis Akibat Pemberitaan Media Tentang Kasus Korupsi Pengadaan Pupuk: Studi Kasus Hubungan Media Humas PT Perkebunan Nusantara XII (PERSERO) Surabaya. Jurnal Ilmu Komunikasi. Teori komunikasi.

${ }^{43}$ Sendjaja, S. D., Rahardjo, T., Pradekso, T., \& Sunarwinadi, I. R. (2014). 
komunikasi akan dihandle kedalam dan antara kantor. Mendapatkan pesan yang benar adalah kritis, dan begitu juga pemilihan media komunikasi yang benar ${ }^{44}$.

\section{Pedoman Komunikasi Krisis ${ }^{45}$}

Secara umum dipercaya bahwa 24 jam pertama adalah krusial karena karena media butuh mengetahui apa yang terjadi sehingga mereka dapat menyampaikan kepada audiens mereka ${ }^{46}$. Ada kekosongan informasi yang, jika ditinggalkan tanpa diisi oleh organisasi akan pelik, akan diisi mereka oleh yang lain. Lamanya perusahaan menunggu, lebih mungkin kebohongan akan diteriman sebagai kebenaran. Itu adalah alasan yang lebih direkomendasikan oleh konsultan di lapangan, yakni mengatakan kebenaran dan mengatakannya dengan cepat. Mengatakan kebenaran di depan adalah paling sederhana dan cara yang sangat efektif menjinakkan permusuhan publik, tidak masalah bagaimana buruknya insiden. Lebih dari pada sibuk dengan melindungi diri sendiri dari kewajiban, perusahaan harus menunjukkan rasa integritas, tanggung jawab, dan komitmen yang kuat ${ }^{47}$.

Sebuah organisasi dapat menggunakan sejumlah kesempatan untuk menyebarkan informasi itu ataupu mengatakan itu adalah sisi dari sejarah terhadap cuaca yang membawa badai krisis. Hal ini meliputi: press release, press kits, news conference, dan wawancara satu-satu dengan berbagai media. Press release adalah suatu pernyataan yang dicetak yang menggambarkan bagaimana organisasi melakukan respons terhadap krisis dan siapa yang bertanggung jawab. Press Kit adalah paket informasi tentang perusahaan, mencakup nama-nama dan gambar eksekutifnya, lembar fakta, dan tonggak

${ }^{44}$ Febriyansyah, A. R., Christin, M., \& Imran, A. I. (2016). Strategi media relations pt. pelabuhan tanjung priok dalam menanggapi krisis. Jurnal Kajian Komunikasi, 4(2), 229-242.

${ }^{45}$ Negara, P. M. N. P. A., \& Nomor, R. B. R. I. (29). Tahun 2011 tentang Pedoman Umum Pengelolaan Komunikasi Krisis di Lingkungan Instansi Pemerintah.

46 Suharyanti, S., \& Sutawidjaya, A. H. (2013). Analisis Krisis Pada Organisasi Berdasarkan Model Anatomi Krisis dan Perspektif Public Relations. Journal Communication Spectrum, 2(2).

47 Hardjana, A. A. (2008). Komunikasi dalam Manajemen Reputasi Korporasi. Jurnal ilmu komunikasi, 5(1), 1-24. 
kunci dalam sejarah perusahaan. Dalam peristiwa krisis, item terakhir yang dicakup oleh press kit adalah press release khusus yang berhubungan dengan insiden terbaru. Paket ini siap didistribusikan kepada media ketika krisis berhenti ${ }^{48}$.

Mengatakan apa yang organisasi anda lakukan untuk menangani krisis penting khususnya kepada keluarga ataupun relasi korban yang dekat. Anggota keluarga ini harus ditangani dengan pernuh kepekaan. Ketiadaan perhatian dan empati dapat membawa pada persepsi tentang arogansi. Hal itu juga penting untuk ditambahkan pada diskusi tentang apa yang sedang dilakukan, sebuah rencana menunjukkan bagaiman krisis yang mirip akan dihindari di masa depan. Ini adalah ketika input dari tim manajemen krisis dan ahli teknik lainnya menjadi sangat berharga bagi juru bicara. Tambahan, untuk menyediakan ikhtisar tentang kemajuan yang dibuat untuk mengatasi krisis, juru bicara seharusnya melibatkan spesialis teknis yang lebih ahli dan informasi latar belakang yang terinci. Ini terutama selama konferensi pers. Juga, mendaftarkan dukungan pihak ketiga yang objektif untuk berbicara atas kepentingan organisasi yang dapat mengurangi kerusakannya ${ }^{49}$.

\section{E. Mengelola Setelah Krisis}

Sangat mungkin bagi sebuah organisasi untuk mengalami pertumbuhan dan kemakmuran setelah krisis ${ }^{50}$. Pemimpin yang efektif tahu bagaimana mengubah kejadian negatif seperti krisis ke dalam sebuah pertumbuhan dan pengalaman belajar. Hal itu adalah tentang mencari di luar krisis yang ada ke dalam masa depan. Banyak organisasi yang berwawasan kedepan saat ini menjalankan apa yang para ahli rekomendasikan; itu adalah, ujung dari sebuah krisis, manajemen puncak harus meluncurkan sebuah evaluasi (sebaiknya dilakukan oleh pihak ketiga) efektifitas organisasi dalam mengelola krisis. Sebuah evaluasi seharusnya mencakup efektifitas dalam berkomunikasi dengan kelompok stakeholder kunci dan efektifitas

${ }^{48}$ Achua, C. F., \& Lussier, R. N. (2013), op.cit

${ }^{49}$ Achua, C. F., \& Lussier, R. N. (2013), Ibid

${ }^{50}$ Berdasarkan pengalaman PM Gontor yang mengalami masa pendirian, bertahan, stagnasi, perkembangan, dan ekspansi menjadi korporasi pesantren terbesar di Indonesia. Lihat Syahrul, S. (2018). Strategi Pengembangan Lembaga Pendidikan: Menggali Spirit PM Gontor 7 Putera, Sulawesi Tenggara. Shautut Tarbiyah, 24(2), 334-360. 
dalam menghadapi akar penyebab krisis. Analisis harus fokus pada yang terkait dengan bagaimana tim krisis dan rencana manajemen krisis dilakukan secara efektif, bagaimana organisasi memperlakukan korban dan anggota keluarga secara efektif, dan apa yang dikerjakan paling tidak dalam mitigasi masalah. Pertanyaan-pertanyaan ini relevant untuk banyak alasan, paling penting yang merupakan pelajaran yang diajarkan yang dapat membantu mencegah krisis di masa depan ${ }^{51}$.

Terbukti dari diskusi sejauh ini bahwa komunikasi krisis yang efektif sisanya pada prinsip-prinsip berikut: persiapan pada krisis, respons cepat, bertindak dengan integritas, dan ungkapkan sepenuhnya. Garis bawah, menurut seorang peneliti, adalah sadar tentang "tiga As": mengakui atau menerima situasi, menentukan apa tindakan yang anda ambil untuk memuat dan memperbaiki kerusakan, dan katakan kepada publik apa yang anda akan lakukan untuk menghindari pengulangan di masa depan ${ }^{52}$.

Jika ada satu kepastian dalam kehidupan organisasi hari ini, itu adalah perubahan yang akan terjadi ${ }^{53}$. Banyak organisasi menemukan bahwa mereka bekerja dalam lingkungan dengan benturan yang tinggi dimana tingkat perubahan terputus-putus, menjadikan model kepemimpinan masa lalu yang telah usang. Sebuah rekomendasi dalam konteks ini adalah bahwa sukses di masa depan akan tergantung pada kemampuan organisasi untuk belajar dan beradaptasi $^{54}$.

\section{Kesimpulan}

Kepemimpinan tidaklah menyandarkan pada pengaruh pribadi an sich pada seorang pemimpin. Kepekaan yang tinggi dibutuhkan agar seorang pemimpin selalu sadar atas berbagai kondisi yang melingkupi lembaga yang dipimpinnya. Demikian juga pada lembaga pendidikan, kepemimpinan mesti dibarengi dengan penguasaan atas kondisi-kondisi lingkungan yang senantiasa berubah. Kemampuan manajerial harus menjadi penunjang dalam kerja-kerja kepemimpinan,

${ }^{51}$ Achua, C. F., \& Lussier, R. N. (2013), Ibid

${ }^{52}$ Purwaningwulan, M. M., Sos, S., \& Si, M. (2013). Public Relations dan Manajemen Krisis. ILMU KOMUNIKASI, 11.

${ }^{53}$ Winardi, J. (2005). Manajemen perubahan. Jakarta: Prenada Media.

${ }^{54}$ Senge, P. M. (2014). The fifth discipline fieldbook: Strategies and tools for building a learning organization. Crown Business. 
tidak hanya pada kegiatan-kegiatan terprogram, lebih dari itu adalah desain kesiapan sekolah dalam mengelola krisis.

\section{Daftar Pustaka}

Achua, C. F., \& Lussier, R. N. (2013). Effective leadership. SouthWestern Cengage Learning.

Aditya, V., \& Nasrianti, L. F. (2017). KOMUNIKASI KRISIS DI SOSIAL MEDIA Analisis Manajemen Krisis Iklan\# PilihAman Grab Bike Indonesia. Prosiding Magister Ilmu Komunikasi, 1(2).

Adnan, M. A., \& Kumiasih, E. (2000). Analisis tingkat kesehatan perusahaan untuk memprediksi potensi kebangkrutan dengan pendekatan Altman (Kasus pada sepuluh perusahaan di Indonesia). Indonesian Journal of Accounting and Auditing, 4(2), 131-161.

Badarwan, B. (2018). Dinamika Sekolah Pinggiran dalam Perspektif Kepemimpinan Krisis di Kota Kendari. Shautut Tarbiyah, 24(2), 181-203.

Bolman, L. G., \& Deal, T. E. (1991). Reframing organizations. San Francisco: Jossey-Bass Publishers.

Febriyansyah, A. R., Christin, M., \& Imran, A. I. (2016). Strategi media relations pt. pelabuhan tanjung priok dalam menanggapi krisis. Jurnal Kajian Komunikasi, 4(2), 229-242.

Fitrah, M. (2017). Peran kepala sekolah dalam meningkatkan mutu pendidikan. Jurnal Penjaminan Mutu, 3(1), 31-42.

Hakim, M. N. (2016). Implementasi Manajemen Berbasis Sekolah Dalam Mewujudkan Sekolah Islam Unggulan. Nidhomul Haq: Jurnal Manajemen Pendidikan Islam, 1(2), 104-114.

Hanafi, M. (2014). Manajemen risiko.

Hardjana, A. A. (2008). Komunikasi dalam Manajemen Reputasi Korporasi. Jurnal ilmu komunikasi, 5(1), 1-24.

Istiningrum, A. A. (2011). Implementasi penilaian risiko dalam menunjang pencapaian tujuan instansi pendidikan. Jurnal Pendidikan Akuntansi Indonesia, 9(2).

Kristiawan, A., \& Yunanto, K. T. (2012). Pemimpin, Budaya Organisasi, dan Perilaku Etis. In Prosiding Seminar Nasional.

Lestari, D. I. (2013). Penerapan Strategi Komunikasi Krisis Terhadap Krisis Akibat Pemberitaan Media Tentang Kasus Korupsi 
Pengadaan Pupuk: Studi Kasus Hubungan Media Humas PT Perkebunan Nusantara XII (PERSERO) Surabaya. Jurnal Ilmu Komunikasi.

Maulana, H., \& Verawati, V. (2014). Pengaruh Gaya Kepemimpinan Transformasional Terhadap Keterikatan Karyawan: Studi Pada Pt. Pertamina (Persero). JPPP-Jurnal Penelitian dan Pengukuran Psikologi, 3(2), 47-51.

Negara, P. M. N. P. A., \& Nomor, R. B. R. I. (29). Tahun 2011 tentang Pedoman Umum Pengelolaan Komunikasi Krisis di Lingkungan Instansi Pemerintah.

Nova, F. (2009). Crisis public relations: bagaimana PR menangani krisis perusahaan. Grasindo.

Purwaningwulan, M. M., Sos, S., \& Si, M. (2013). Public Relations dan Manajemen Krisis. ILMU KOMUNIKASI, 11.

Sa'diyah, H. (2018). Manajemen Krisis Universitas Islam Indonesia (UII) Yogyakarta dalam Mengatasi Kasus Mapala Unisi. Jurnal Ilmu Komunikasi AKRAB, 2(1).

Sendjaja, S. D., Rahardjo, T., Pradekso, T., \& Sunarwinadi, I. R. (2014). Teori komunikasi.

Senge, P. M. (2014). The fifth discipline fieldbook: Strategies and tools for building a learning organization. Crown Business.

Suharyanti, S., \& Sutawidjaya, A. H. (2013). Analisis Krisis Pada Organisasi Berdasarkan Model Anatomi Krisis dan Perspektif Public Relations. Journal Communication Spectrum, 2(2).

Syahrul, S. (2017). Tanggung Jawab Sosial Pesantren: Studi pada Pondok Pesantren Al Munawwarah Pondidaha, Konawe. Shautut Tarbiyah, 23(2), 120-134.

Syahrul, S. (2016). Readines Frame: Analisis Kerangka Kesiapan dalam Transformasi Pendidikan Tinggi (Pengalaman Iain Kendari). Al-Ta'dib, 9(1), 162-181.

Syahrul, S. (2015). Kepemimpinan dan Inovasi Lembaga Pendidikan (Pengalaman Pondok Gontor VII Putra Sulawesi Tenggara). AlTa'dib, 8(1), 82-100.

Syahrul, S. (2017). Perencanaan Strategis dan Praktiknya di Perguruan Tinggi. Shautut Tarbiyah, 23(1), 142-159.

Syahrul, S. (2018). Strategi Pengembangan Lembaga Pendidikan: Menggali Spirit PM Gontor 7 Putera, Sulawesi Tenggara. Shautut Tarbiyah, 24(2), 334-360. 
Warsono, H., \& Dwimawanti, I. H. (2016, July). The Model Organization of Early Childhood Education in Organizational Capacity Development. In 2016 International Conference on Public Management. Atlantis Press.

Winardi, J. (2005). Manajemen perubahan. Jakarta: Prenada Media. 